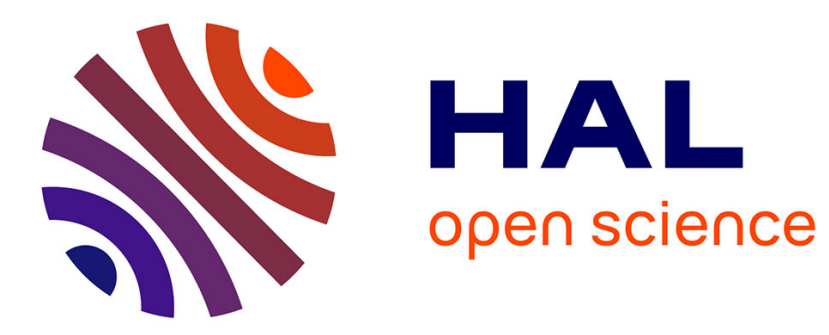

\title{
Design and characterization of a dual-band miniaturized circular antenna for deep in body biomedical wireless applications
}

Shuoliang Ding, Stavros Koulouridis, Lionel Pichon

\section{- To cite this version:}

Shuoliang Ding, Stavros Koulouridis, Lionel Pichon. Design and characterization of a dual-band miniaturized circular antenna for deep in body biomedical wireless applications. International Journal of Microwave and Wireless Technologies, 2020, pp.1-8. 10.1017/S1759078720000197 . hal-02522677

\section{HAL Id: hal-02522677 \\ https://hal.science/hal-02522677}

Submitted on 27 Mar 2020

HAL is a multi-disciplinary open access archive for the deposit and dissemination of scientific research documents, whether they are published or not. The documents may come from teaching and research institutions in France or abroad, or from public or private research centers.
L'archive ouverte pluridisciplinaire HAL, est destinée au dépôt et à la diffusion de documents scientifiques de niveau recherche, publiés ou non, émanant des établissements d'enseignement et de recherche français ou étrangers, des laboratoires publics ou privés. 


\title{
Design and Characterization of a Dual-Band Miniaturized Circular Antenna for Deep in Body Biomedical Wireless Applications
}

\author{
Shuoliang Ding ${ }^{1}$, Stavros Koulouridis ${ }^{2}$, Lionel Pichon ${ }^{1}$ \\ ${ }^{1}$ Group of Electrical Engineering - Paris, UMR 8507 CNRS, CentraleSupelec, Université Paris-Sud, Sorbonne Université, \\ Gif-sur-Yvette, France. Email: shuoliang.ding @ geeps.centralesupelec.fr \\ ${ }^{2}$ Electrical and Computer Engineering Department, University of Patras, Patras, Greece. E-mail: stavros.koulouridis@ upatras.gr
}

\begin{abstract}
In this paper, a novel miniaturized implantable circular antenna is presented. It supports both wireless information communication and wireless energy transmission at the Medical Device Radiocommunication band (MedRadio 402-405MHz) and the Industrial, Scientific and Medical bands (ISM 902.8-928 MHz). Antenna is circular to avoid sharp edges while miniaturization is achieved by adding two circular slots to the patch. Main scenario includes embedding into the muscle layer of a cylindrical three-layer model of a human arm for which several parameters are analyzed (resonance, radiation pattern and Special Absorption rate (SAR)). Power transmission efficiency and interaction distance limits to ensure connection are also evaluated. At last, the design is validated by an experimental measurement in an anechoic chamber, and some new improvements are proposed.
\end{abstract}

Index Terms-Implantable antenna, planar inverted-F antenna, wireless power transmission, industrial, scientific and medical (ISM) band, Medical Device Radiocommunications (MedRadio) band.

\section{INTRODUCTION}

Recently, with the population's ageing acceleration, health care has gained more and more focus in the society. Implantable medical devices (IMD) have attracted much attention and have been popularly studied thanks to their huge potential to be light, small and utilized in various pragmatic applications. However, the question of designing an efficient system that supports both power and data transmission for IMDs remains crucial for researchers.

Radiation, as one of the mainly used methods for wireless charging, is more robust to location change and has a smaller size of the reception device than the induction and the midfield transmission method. For biomedical uses, several frequency bands are authorized: Medical Device Radiocommunication (MedRadio) Service band (401-406 $\mathrm{MHz}$ ), and the Industrial, Scientific, and Medical (ISM) bands (433.1-434.8 MHz, 868-868.6 MHz, 902.8-928MHz and 2.4-2.5 GHz) [1-3]. Since the team of L.C. Chirwa [4] has published a study about the performances of an implanted source in human intestine under different frequencies in 2003, many research teams have carried out successively their own designs or analyses [5-7]. Some designs of antenna possess multiple resonant frequencies but have bigger sizes [8]; others are smaller in size but resonate at higher frequency which will certainly lead to higher losses in deeper implantation [9]; moreover, many researches are performed in the skin layer, which adds difficulties to medical surgery and is less realistic [10-11].

In order to address such issues, authors proposed a miniaturized circular antenna in [12]. Antenna has two different resonant frequencies at $403 \mathrm{MHz}$ and $915 \mathrm{MHz}$ which correspond to data and power transmission respectively. Furthermore, the antenna is designed to be deep implanted into the muscle tissue and not relatively sensitive to variations of implantation depth and thus robust to changes of environment. A full wave 3D simulation of the global wireless link showed the validity of the above.

This paper is an extended version of the work presented in [12]. Here, an experimental validation of the design is added, including many details on the experimental process and comparison between simulations in human and pork tissues. Pork tissue is usually used in validation measurements. Furthermore, the antenna design is improved in order to achieve a good performance during the experiment. The experimental validation of the wireless link with the fabricated proposed antenna is performed in an anechoic chamber. Ground pork meat is used as biological surrounding environment of the antenna. A comparison between numerical prediction of the reflection coefficient and the measurement results validate our approach.

In section II, the detailed antenna structure is firstly presented. Numerical results (such as reflection coefficient, impedance, radiation pattern, specific absorption rate (SAR)) are subsequently analyzed in section III. Then in section IV, the in-body/off-body interaction with an external dipole is analyzed. Finally, in section $\mathrm{V}$, the measurement scenario and results are presented for a well defined environment.

\section{ANTENNA DESIGN}

A precise parametric model of the antenna is shown in Fig 1. It is made up of a ground plane, a patch, a substrate between them, a superstrate over the patch and a coaxial 
feeding. The substrate and superstrate are made from the same material: Rogers RO $3210\left(\varepsilon_{\mathrm{r}}=10.2, \tan \delta=0.003\right)$. Both the patch and the ground plane are circular, connected with a ground wire (located at point $\mathrm{W}$, diameter $0.3 \mathrm{~mm}$ ) which helps to decrease the antenna size. Two circular slots are also cut from the patch in order to have two operating frequencies at $402 \mathrm{MHz}$ and $915 \mathrm{MHz}$. The coaxial cable (located at point $F)$ is standardized to $50 \Omega$ impedance. All the parameters marked in Fig 1. are presented in Table I.

TABLE I. ANTENNA PARAMETERS

\begin{tabular}{cccc}
$\begin{array}{c}\text { Parameter } \\
\text { Name }\end{array}$ & Value (mm) & $\begin{array}{c}\text { Parameter } \\
\text { Name }\end{array}$ & Value (deg) \\
\hline R1 & 4.9 & $\theta 1$ & 70 \\
R2 & 3.76 & $\theta 2$ & 18 \\
w1 & 0.15 & $\theta 3$ & 163 \\
w2 & 0.32 & $\theta 4$ & 109 \\
t1 & 0.64 & & \\
t2 & 0.64 & & \\
D & 10.7 & &
\end{tabular}

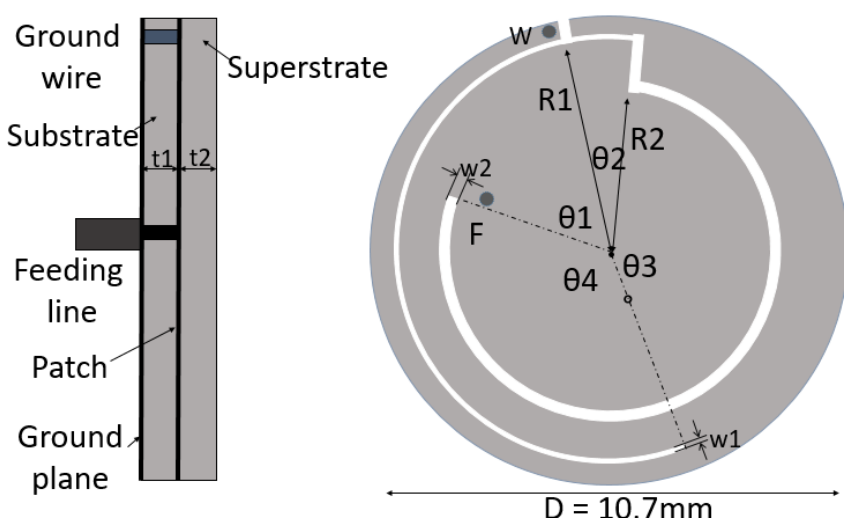

Fig 1. Geometry of the developped circular antenna

The antenna has a circular shape to avoid sharp edges. Table II presents the comparison results between the circular PIFAs that are designed in previous publications and the antenna designed in this paper, which is smaller, embedded deeper and resonating at lower frequencies to reduce losses.

TABLE II. COMPARISON WITH PREVIOUS DESIGNS

\begin{tabular}{|c|c|c|c|c|c|}
\hline $\begin{array}{c}\text { Refere } \\
\text { nce }\end{array}$ & $\begin{array}{c}\text { Antenna } \\
\text { Radius } \\
(\mathbf{m m})\end{array}$ & $\begin{array}{c}\text { Gain in } \\
\text { tissue } \\
\text { (dB) }\end{array}$ & $\begin{array}{c}\text { Resonant } \\
\text { Frequency } \\
(\mathbf{G H z})\end{array}$ & $\begin{array}{c}\text { Examine } \\
\text { d Depth } \\
(\mathrm{mm})\end{array}$ & $\begin{array}{c}\text { Model } \\
\text { used }\end{array}$ \\
\hline [7] & 8,5 & -15 & 2,4 & $2-3 \mathrm{~mm}$ & $\begin{array}{l}\text { Muscle + } \\
\text { Phantom }\end{array}$ \\
\hline [9] & 6 & -33.41 & 0,$4 ; 0,9$ & $10 \mathrm{~mm}$ & $\begin{array}{l}\text { Skin } \\
\text { cube }\end{array}$ \\
\hline [11] & 7,5 & -49.16 & 0,$4 ; 2,4$ & $10 \mathrm{~mm}$ & $\begin{array}{l}\text { Skin } \\
\text { cube }\end{array}$ \\
\hline [13] & 2,5 & N/A & 2,4 & $25 \mathrm{~mm}$ & $\begin{array}{l}\text { Skin } \\
\text { cube }\end{array}$ \\
\hline $\begin{array}{l}\text { This } \\
\text { paper }\end{array}$ & 5,35 & -33.65 & 0,$4 ; 0,9$ & $\begin{array}{c}10-16 \\
\mathrm{~mm}\end{array}$ & $\begin{array}{c}\text { Three- } \\
\text { layer } \\
\text { model }\end{array}$ \\
\hline
\end{tabular}

The antenna in this paper is analyzed in a more detailed model of the tissue as compared with previous works. In [7], the antenna is embedded only $3 \mathrm{~mm}$ deep which is not as realistic as in this paper because the implantation at this depth is more vulnerable and more difficult to realize. In [9], this study is performed with anatomical tissues and thus is for more specific uses and less useful for other general implantation cases. The implantation depth is $10 \mathrm{~mm}$ which is less deep and the antenna is slightly bigger than in this paper. In [11] and [13], the antennas are all implanted into big skin boxes. It is less realistic since human skins are usually not that thick.

The antenna in this paper is embedded in the human tissue model shown in Fig 2. As in [6], a three-layer cylindrical human arm model is used in this paper. The radius of each layer is: bone $(25 \mathrm{~mm})$, muscle $(25 \mathrm{~mm}$ $47.5 \mathrm{~mm})$ and skin $(47.5 \mathrm{~mm}-50 \mathrm{~mm})$. The implantation depth is calculated as the distance between the center of the radiating patch and the external surface of the skin layer. The length of the "arm" is set to the minimum value to ensure proper consideration of a "realistic" case and avoid heavy calculations.

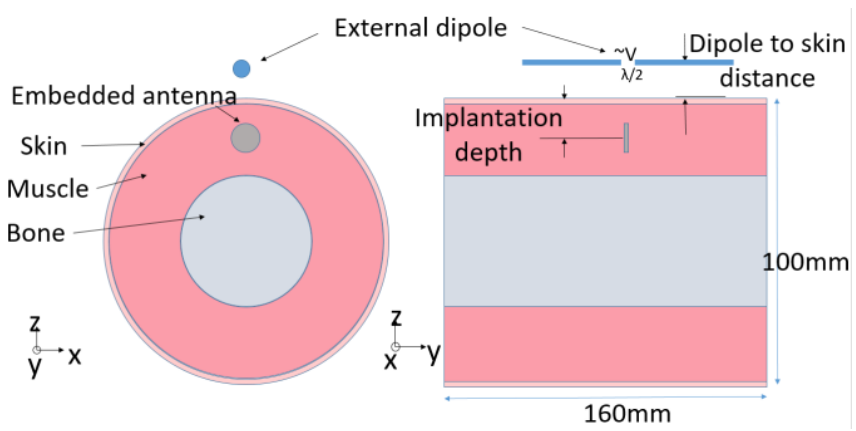

Fig 2. Geometry of the three-layer arm model

TABLE III. DIELECTRIC CONSTANTS OF HUMAN TISSUE [14]

\begin{tabular}{|c|c|c|c|c|}
\hline \multicolumn{2}{|c|}{ Frequency } & \multirow{2}{*}{\begin{tabular}{|l} 
Bone \\
13.22
\end{tabular}} & \multirow{2}{*}{$\begin{array}{c}\text { Muscle } \\
57.15\end{array}$} & \multirow{2}{*}{$\begin{array}{l}\text { Skin } \\
46.81\end{array}$} \\
\hline 403MHz & $\varepsilon_{\mathrm{r}}$ & & & \\
\hline \multirow{3}{*}{$915 \mathrm{MHz}$} & $\sigma(\mathrm{S} / \mathrm{m})$ & 0.09 & 0.79 & 0.69 \\
\hline & $\varepsilon_{\mathrm{r}}$ & 12.45 & 54.98 & 41.35 \\
\hline & $\sigma(\mathrm{S} / \mathrm{m})$ & 0.15 & 0.93 & 0.85 \\
\hline
\end{tabular}

\section{ANTENNA CHARATERISTICS}

\section{A. Reflection coefficients}

Reflection coefficient is a key factor to characterize the resonant frequency of an antenna. Figure 3(a) and Figure 3 (b) characterize the reflection coefficient $\left(S_{11}\right)$ of the proposed antenna when implanted into the three-layer arm model at the depth from $10 \mathrm{~mm}$ to $16 \mathrm{~mm}$ at $403 \mathrm{MHz}$ and $915 \mathrm{MHz}$. The human tissue dielectric constants (relative permittivity $\varepsilon_{\mathrm{r}}$ and electrical conductivity $\sigma$ ) at corresponding frequencies are shown in Table III. The contents in Table III are extracted from the CST database. All the numerical results are obtained with CST Studios [14] software.

As seen in the S11 figure, the designed antenna is not sensitive to the implantation depth. The $-10 \mathrm{~dB}$ bandwidth at 
$403 \mathrm{MHz}$ and $915 \mathrm{MHz}$ are $80 \mathrm{MHz}$ and $60 \mathrm{MHz}$, which covers the entire corresponding authorized band.
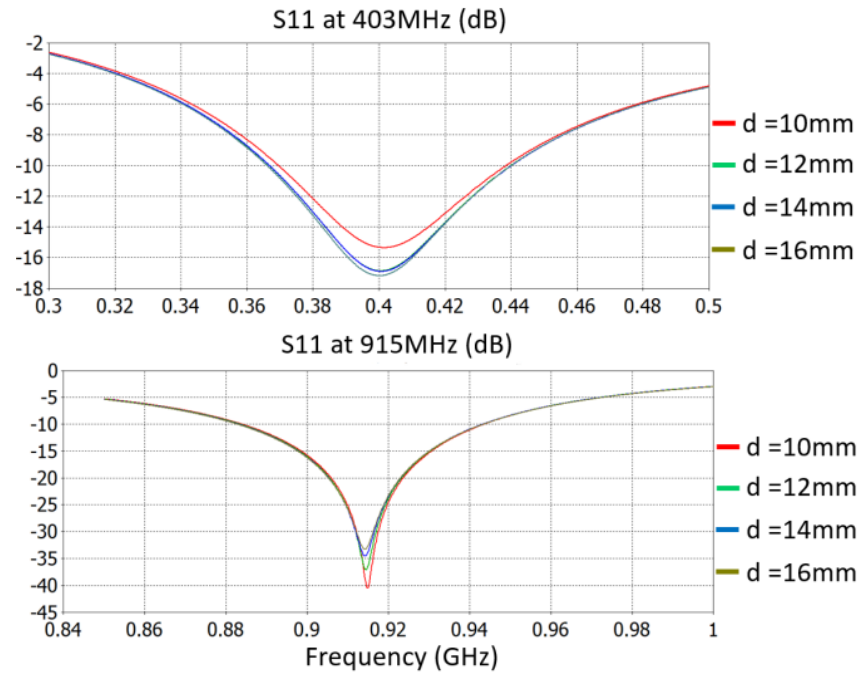

Fig 3. Reflection coefficient of the antenna ([a] at $400 \mathrm{MHz}$ and [b] at $915 \mathrm{MHz}$

\section{B. Radiation pattern \& efficiency}

The radiation pattern is calculated in the center of the frequency band: $403 \mathrm{MHz}$ and $915 \mathrm{MHz}$. The 2-D radiation patterns are presented in Figure 4.

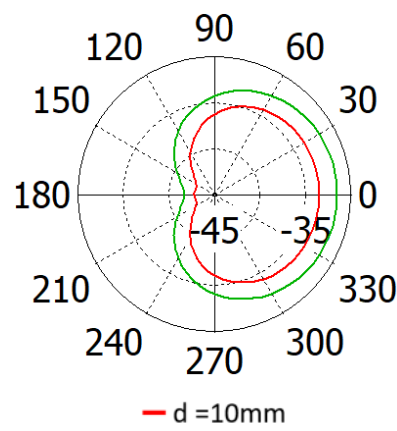

[a]

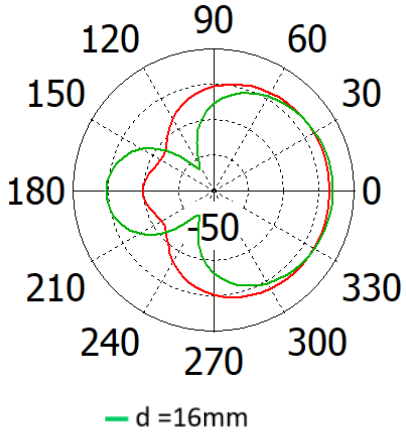

[b]
Fig 4. 2D radiation pattern of the antenna at 10 and $16 \mathrm{~mm}$ implatation depth ([a] at $403 \mathrm{MHz}$ and $[\mathrm{b}]$ at $915 \mathrm{MHz}$ )

The antenna is implanted in $10 \mathrm{~mm}$ depth. At MedRadio band $(403 \mathrm{MHz})$, the maximum gain in far field is around $33.5 \mathrm{~dB}$ and towards $\mathrm{Z}$ axis (see Fig 2 for axis positioning). At ISM band $(915 \mathrm{MHz})$, the gain is $-33.65 \mathrm{~dB}$. It is worth pointing out that the antenna has better maximum gain at deeper location: at $16 \mathrm{~mm}$ depth, its gain increases to $-31.6 \mathrm{~dB}$ at $403 \mathrm{MHz}$ and $-33.1 \mathrm{~dB}$ at $915 \mathrm{MHz}$ since the radiation pattern has a narrower main lobe.

A gain comparison is also presented in Table II. In [7], the designed antenna has a gain of $-15 \mathrm{~dB}$ when implanted into a muscle cylinder with a tissue-mimicking phantom. But the antenna is embedded only $3 \mathrm{~mm}$ deep which is not as realistic as in this paper because the implantation at this depth is more vulnerable and more difficult to realize. In [9], the antenna has a similar size with the one in this paper, the gain at $915 \mathrm{MHz}$ is $-33.41 \mathrm{~dB}$ when implanted into an anatomical head tissue. But this study is for more specific uses and less useful for other general implantation cases. The implantation depth is $10 \mathrm{~mm}$ which is less deep and the antenna is slightly bigger than in this paper. In [11], the antenna has a gain of $-49.16 \mathrm{~dB}$ at $403 \mathrm{MHz}$ when implanted $10 \mathrm{~mm}$ into skin box which is lower than the one here.

\section{C. $S A R$}

Special Absorption Rate (SAR) is a vital parameter that indicates the safety level of an embedded antenna, it represents the average amount of electromagnetic power that can be absorbed by human body. The two IEEE standards about SAR limits [15] [16] point out that the value of SAR of every $1 \mathrm{~g}$ or $10 \mathrm{~g}$ of human tissue cannot be higher than $1.6 \mathrm{~W} / \mathrm{kg}$ and $2 \mathrm{~W} / \mathrm{kg}$ respectively. In Table IV, it is given the maximum input power for the antenna that satisfies each SAR limits at $403 \mathrm{MHz}$ and $915 \mathrm{MHz}$ for implantation depths of 10 or $16 \mathrm{~mm}$.

TABLE IV. MAXIMUM INPUT POWER FOR ANTENNA

\begin{tabular}{l|cccc} 
Max input power $(\mathbf{m W})$ & \multicolumn{2}{c}{ 1g-average } & \multicolumn{2}{c}{ 10g-average } \\
Implantation depth $(\mathbf{m m})$ & $\mathbf{1 0 m m}$ & $\mathbf{1 6 m m}$ & $\mathbf{1 0 m m}$ & $\mathbf{1 6 m m}$ \\
\hline $\mathbf{4 0 3 M H z}$ & 15.38 & 14.99 & 72.22 & 71.17 \\
$\mathbf{9 1 5 M H z}$ & 14.08 & 14.01 & 86.33 & 91.19 \\
\hline
\end{tabular}

\section{Surface current}

The surface current is also an important factor, especially during the antenna's design. It shows the polarization of the antenna and the current path on the patch. This helps to adjust the antenna in order to resonate at the right frequency range. Fig 5 shows the surface current on the radiating patch at $402 \mathrm{MHz}$ and $915 \mathrm{MHz}$.

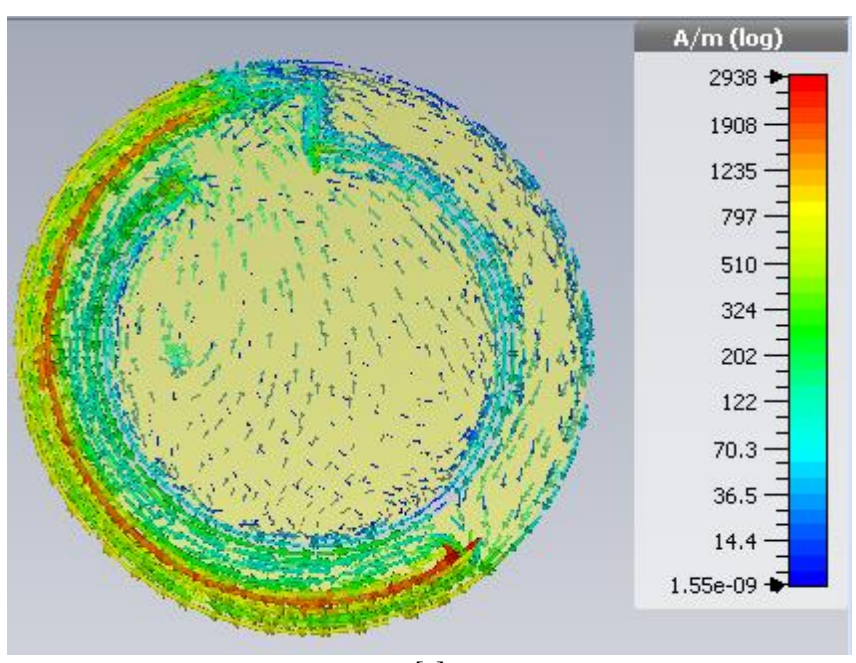

[a] 


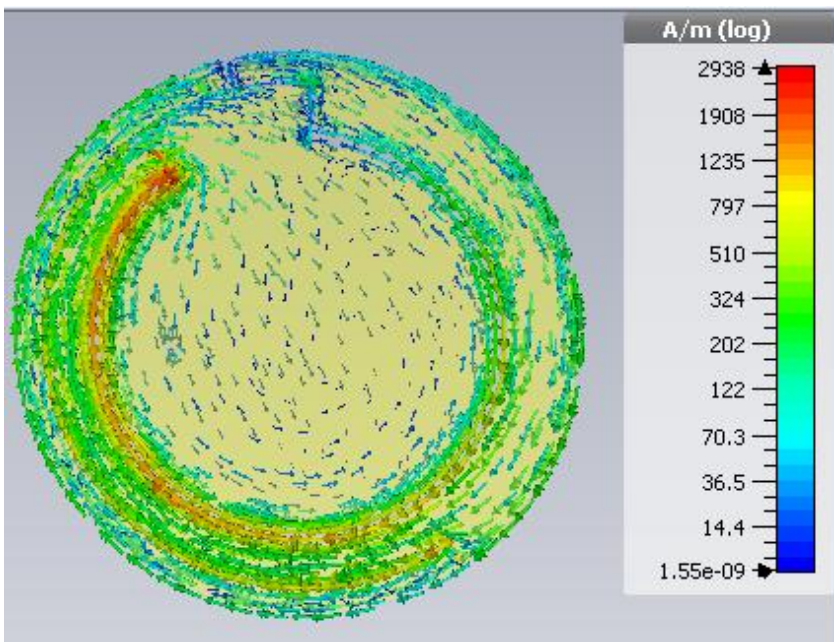

[b]

Fig 5 Suface current on the radiating patch at around phase $=250^{\circ}$ ([a] at $402 \mathrm{MHz}$ and $[\mathrm{b}]$ at $915 \mathrm{MHz})$

As seen, the current along the external slot reaches its peak value when the antenna resonates at $402 \mathrm{MHz}$ and the current along the internal slot reaches its peak at $915 \mathrm{MHz}$. This shows the radiation and the polarization mode of the antenna.

\section{IN-BODY/OFF-BODY INTERACTION}

The antenna is designed to receive energy and emit signal for information exchange at the same time, so it is necessary to evaluate its capacity and efficiency with a more realistic situation in order to examine its performances and also to choose the best energy transmitting frequency band. In this section, a half-wavelength (in air) dipole is used as an external device for both energy and information transfer at the operating frequencies as shown in Figure 2.

The external device is located face-to-face with the main lobe of the antenna at its operating frequency.

\section{A. As a reception device from transmission dipole}

The value of power received is a significant parameter to evaluate the performance of the implantable device as a reception device. In Table $\mathrm{V}$, the power received by the embedded antenna from the external dipole as well as the implantation depth and the dipole to skin distance in each case is provided. It should be noted that for each frequency band, there exist different radiated power limits: $-16 \mathrm{dBm}$ $(25 \mu \mathrm{W})$ at MedRadio band $(401-406 \mathrm{MHz})$ [17] and $30 \mathrm{dBm}$ (1W) at ISM band $(902-928 \mathrm{MHz})$ [18].

With the maximum authorized input power, antenna is able to receive 4000 times more energy (nearly 1000 times when embedded deeper) in the ISM band than in the MedRadio band. Therefore, in our case, the ISM band (902$928 \mathrm{MHz}$ ) is chosen as the energy transmission band. The SAR value in both cases are much lower than the limits.

\section{TABLE V. RESULTS AS RECEPTION DEVICE}

\begin{tabular}{cccccc}
$\begin{array}{c}\text { Embed } \\
\text { ded } \\
\begin{array}{c}\text { Depth } \\
(\mathrm{mm})\end{array}\end{array}$ & $\begin{array}{c}\text { External } \\
\text { Dipole- } \\
\text { Arm } \\
\text { Surface } \\
\text { Distance } \\
(\mathrm{mm})\end{array}$ & $\begin{array}{c}\text { Max } \\
\text { Authorized } \\
\text { Emission } \\
\text { Power } \\
(\mathrm{dBm})\end{array}$ & $\begin{array}{c}\text { Max } \\
\text { Power } \\
\text { Received } \\
(\mathrm{dBm})\end{array}$ & $\begin{array}{c}\text { S } \\
\text { Avera } \\
\text { ge } \\
(\mathrm{W} / \mathrm{kg})\end{array}$ & $\begin{array}{c}\text { Avera } \\
\text { ge } \\
(\mathrm{W} / \mathrm{kg})\end{array}$ \\
\hline 10 & 105 & -16 & -54.5 & $1 * 10^{-4}$ & $3 * 10^{-5}$ \\
10 & 375 & -16 & -66.2 & $2 * 10^{-6}$ & $1 * 10^{-6}$ \\
16 & 375 & -16 & -64.5 & $2 * 10^{-6}$ & $1 * 10^{-6}$ \\
10 & 105 & 30 & -18.5 & 0.32 & 0.22 \\
10 & 375 & 30 & -28.76 & 0.024 & 0.017 \\
16 & 375 & 30 & -31.35 & 0.025 & 0.018
\end{tabular}

\section{B. As an emission device to reception dipole}

It is also necessary to analyze the power redelivered to the external dipole to ensure the possibility to receive signal from the circular antenna when it is embedded inside human body.

\section{TABLE VI. RESULTS AS EMMISSION DEVICE}

\begin{tabular}{|c|c|c|}
\hline $\begin{array}{l}\text { Implantation } \\
\text { depth (mm) }\end{array}$ & $\begin{array}{l}\text { Distance between } \\
\text { energy delivery dipole } \\
\text { and arm surface at } \\
915 \mathrm{MHz}(\mathrm{mm})\end{array}$ & $\begin{array}{l}\text { Maximum distance } \\
\text { between reception dipole } \\
\text { and arm surface at } \\
400 \mathrm{MHz}(\mathrm{mm})\end{array}$ \\
\hline \multirow{3}{*}{10} & 105 & 450 \\
\hline & 375 & 185 \\
\hline & 700 & 105 \\
\hline \multirow{3}{*}{16} & 105 & 425 \\
\hline & 375 & 155 \\
\hline & 625 & 105 \\
\hline
\end{tabular}

In [19], a RF-DC conversion circuit is proposed with an efficiency of $33.1 \%$. If $5 \%$ of total converted DC power is assumed to be used for emitting signal, for each distance between the energy delivery dipole and the skin surface, there is always a corresponding maximum distance between the reception dipole and the skin surface in order to ensure the connection (energy received by the reception dipole $\geq$ $90 \mathrm{dBm}$ [20] which is the minimum power that can be received by mobile phones without information loss) for every different implantation depth. The results are presented in TABLE VI. For example, if a dipole at $915 \mathrm{MHz}$ is fed with $30 \mathrm{dBm}$ and is $375 \mathrm{~mm}$ from the tissue surface while the implanted antenna is at $16 \mathrm{~mm}$ depth, then under the above restrictions an external dipole (at MedRadio ban) should be placed at a maximum distance of $155 \mathrm{~mm}$.

Furthermore, in [21] a table of sensors is presented together with their average power consumption. This also validates the usefulness of the antenna in this paper. 


\section{EXPERIMENTAL MEASUREMENTS}

\section{A. Electromagnetic simulation of the experimental case}

During the experiment, ground pork meat is used as replacement for "human tissue" since it is more realistic than using liquid material to emulate human dielectric properties for various RF frequencies [22]. A cylindrical plastic cup is used to guarantee the cylindrical form to simulate the human arm. Due to the absence of the bone and the tissue shape's change, a further simulation with these experimental materials is realized in order to match the situation. The simulation structure is shown in Fig 6 .

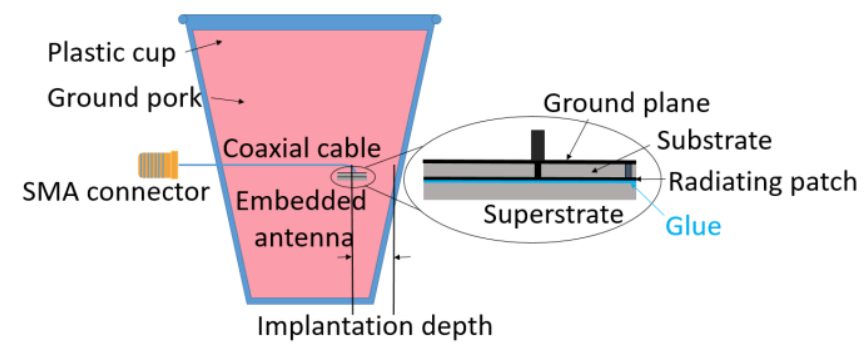

Fig 6. simulation model for predict changes during measurements

The antenna is embedded with the coaxial cable into a cup of ground pork. The thickness of the plastic cup is $0.5 \mathrm{~mm}$ and the implantation depth is calculated from the center of the antenna to the plastic cup's inner surface at the same height level.

It is worth pointing out that although in Fig 6 the antenna is embedded together with the coaxial cable, in the real case, the coaxial cable is no longer used because the antenna will serve as a power receiving device. It will be directly connected with a rectifying circuit and then feed the corresponding sensor.

Although porcine meat has been used frequently as replacement of human tissue thanks to its easy accessibility and its similarity of dielectric properties and biological responses to human tissues [23], there is still slight differences between the electrical properties of two tissues, especially when it is adipose tissue. Table VII shows the electrical characteristics of ground meat and human muscle at $915 \mathrm{MHz}$ [22] [24].

TABLE VII. DIELECTRIC CHARACTERISTICS COMPARISON

\begin{tabular}{c|cc} 
& Ground pork & Human muscle \\
\hline$\varepsilon_{\mathrm{r}}$ & 39.8 & 54.9 \\
$\sigma(\mathrm{S} / \mathrm{m})$ & 0.65 & 0.93
\end{tabular}

Due to this change of environmental characteristics, some fine-tuning should be done to the antenna design in order to obtain the same resonant frequencies as in the simulations. Table VIII shows the parameters of the newly designed and faricated antenna.

In the new design, the two resonant frequencies are moved slightly to lower frequencies (by reducing the radius of the two slots respectively) in order to leave a margin for the frequency shifting caused by dielectric constant's decreasing. Furthermore, a glue layer of $0.8 \mathrm{~mm}\left(\varepsilon_{r} \approx 3.5\right)$ to stick the substrate together with the superstrate is also taken into account. The metallic patch has a diameter of $10.8 \mathrm{~mm}$ but the substrate, superstrate and ground plane's diameters are all increased to $11 \mathrm{~mm}$, in order to cover the patch. This new design avoids the direct contact between the patch and the surrounding tissue and thus becomes more robust to the environmental change and has a higher gain.

This antenna impedance is standardized to $110 \Omega$ in order to obtain a good performance.

\section{TABLE VIII. NEWLY DESIGNED ANTENNA PARAMETERS}

\begin{tabular}{cccc}
$\begin{array}{c}\text { Parameter } \\
\text { Name }\end{array}$ & Value (mm) & $\begin{array}{c}\text { Parameter } \\
\text { Name }\end{array}$ & Value (deg) \\
\hline R1 & 4.82 & $\theta 1$ & 22 \\
R2 & 3.68 & $\theta 2$ & 18 \\
w1 & 0.15 & $\theta 3$ & 141 \\
w2 & 0.32 & $\theta 4$ & 179 \\
t1 & 0.64 & & \\
Dpatch & 10.8 & & \\
Dground & 11 & &
\end{tabular}

\section{B. Measurement results}

The measurements are performed in an anechoic chamber. Fig 7 [a] shows the fabricated antenna in comparison with a euro cent. Fig 7 [b] shows the antenna with glued superstrate and soldered together with the coaxial cable. Fig 7 [c] shows the structure under measurement inside the anechoic chamber. The whole antenna is embedded into the ground pork with a certain implantation depth measured from outside. Then the connector is fixed onto the measurement platform in order to avoid uncertainties.

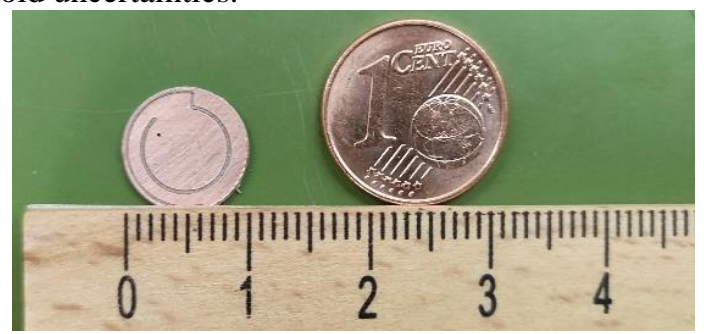

[a]

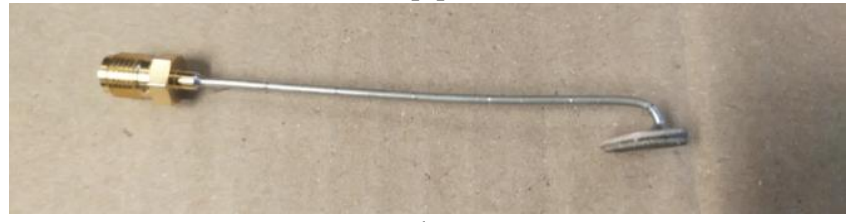

[b] 


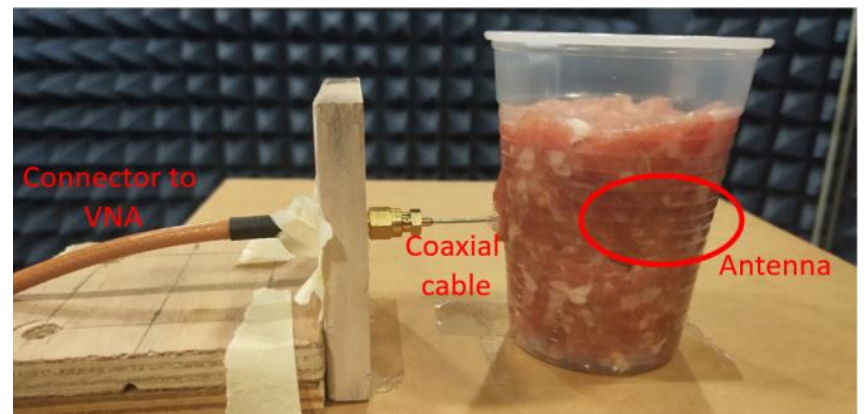

[c]

Fig 7. [a] fabricated antenna comparing with one euro cent [b] complete antenna with coaxial cable and superstrate [c] antenna embedded into minced pork

The coaxial cable is folded behind the main radiating direction in order to minimize the radiation influence that comes from the cable. Moreover, the glue that surrounds the radiating patch which may also lead to the isolation of the antenna from the pork tissue. The scenario is presented in Fig 8 [a].

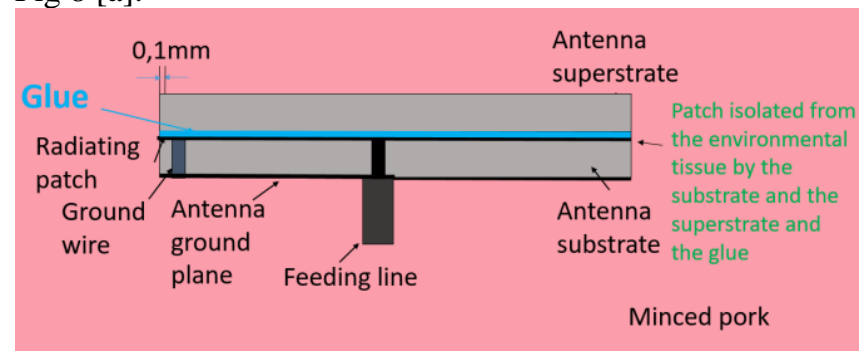

[a]

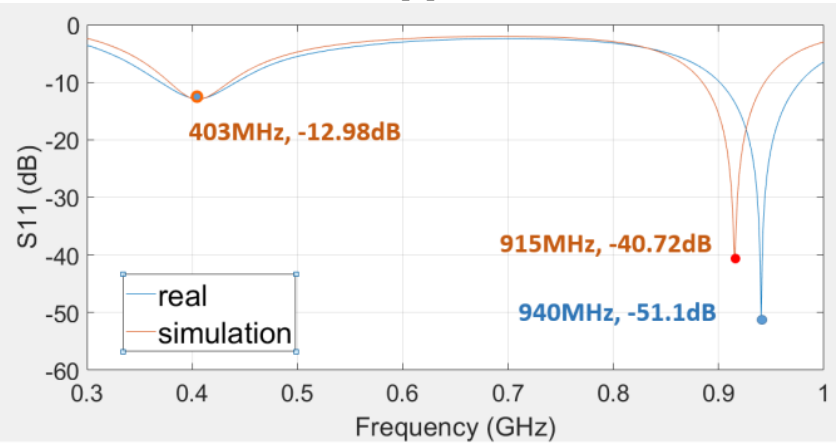

[b]

Fig 8. [a] experimental structure of the fabricated antenna [b] Measurement results compared with simulation results

Fig $8[\mathrm{~b}]$ shows the measured reflection coefficient results obtained by the Vector Network Analyzer Agilent E8363b as compared with the corresponding simulated S11. The results at the first resonant frequency at $403 \mathrm{MHz}$ are in satisfactory agreement. For the second resonant frequency, there is shifting in the resonance of around $25 \mathrm{MHz}$. This is because, in one hand, the dielectric constant of the pork tissue is lower than that of the human muscle; on the other hand, the air bubbles that exist among the ground pork meat may also decrease the equivalent permittivity of the surrounding environment. Therefore, the antenna resonates at a higher frequency than designed. However, in general the measurement results and simulation results match well with each other. In order to validate this assumption, a new simulation using the pork dielectric properties is done and the reflection coefficient $\mathrm{S} 11$ at $915 \mathrm{MHz}$ band is compared with the experimental result. The figure is shown in Fig. 9.

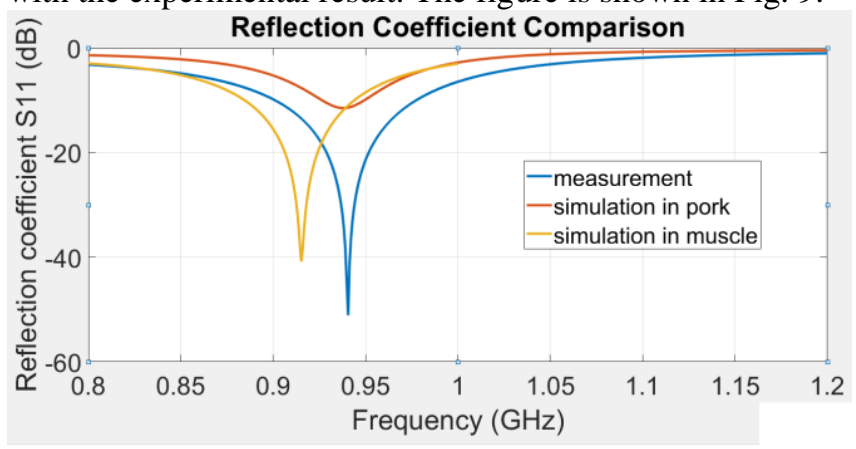

Fig 9. Comparison of different reflection coefficient results

As shown in Fig.9, the simulated S11 result in pork is much closer to the measurement result than the simulation in muscle, which validates the previous assumption, that this shifting is caused by the difference between pork and human tissue.

\section{CONCLUSION}

In this paper, a miniaturized circular antenna is designed for a deep-body wireless biomedical application. The antenna is studied while embedded into a three-layer cylindrical model of arm and its performance is evaluated. The dual resonant frequency which covers MedRadio (401$406 \mathrm{MHz})$ and ISM bands (902-928MHz). The antenna has $31.6 \mathrm{~dB}$ at $403 \mathrm{MHz}$ and $-33.1 \mathrm{~dB}$ at $915 \mathrm{MHz}$ gain respectively. The in-body/off-body link is also analyzed. First we assess the amount of power that could be received from an external dipole at maximum authorized input power in order to select the appropriate energy transmission band. Then the amount of power that could be redelivered to the external device is also calculated, and the distance limits to ensure reliable connection are shown in the paper. Finally, the antenna is fabricated and tested in an anechoic chamber. Although slight differences are observed between the measurement and simulation results, the deviation is acceptable while the source of discrepancies (air bubbles and tissue dielectric property change) is identified.

In the future, several transmission and link budget scenarios will be tested and measured in the anechoic chamber. The newly design antenna will also be tested.

\section{REFERENCES}

[1] "International Telecommunications Union-Radiocommunica- tions (ITU-R), radio regulations, section 5.138 and 5.150," ITU. Geneva, Switzerland, [Online].

[2] Bakogianni S., and Koulouridis S., "An implantable planar dipole antenna for wireless medradio-band biotelemetry devices," IEEE Antennas Wireless Propag. Lett., vol. 15, pp. 234-237, 2016.

[3] FCC. Washington, D.C., USA, Federal Communications Commission 2012. [Online]. Available online: http://www.fcc.gov

[4] Chirwa L. C., Hammond P. A. Roy S., \& Cumming D. R. S. (2003) Electromagnetic radiation from ingested sources in the human 
intestine between $150 \mathrm{MHz}$ and $1.2 \mathrm{GHz}$. IEEE Transactions on Biomedical Engineering, 50(4), 484-492.

[5] Kim J., \& Rahmat-Samii Y. (2004). Implanted antennas inside a human body: Simulations, designs, and characterizations. IEEE Transactions on Microwave Theory and Techniques, 52(8 II), 19341943.

[6] Luu Q. T., Koulouridis S., Diet A., Le Bihan Y., \& Pichon L. (2017). Investigation of inductive and radiating energy harvesting for an implanted biotelemetry antenna. 2017 11th European Conference on Antennas and Propagation, EUCAP 2017, 160-163. .

[7] Ali M. M., Bashar M. E. I., \& Hosain M. K. (2017). Circural Planner Inverted-F Antenna for Implantable Biomedical Applications. 2017 2nd International Conference on Electrical \& Electronic Engineering (ICEEE), 1, 1-4.

[8] Liu C., Guo Y. X., \& Xiao S. (2012). Compact dual-band antenna for implantable devices. IEEE Antennas and Wireless Propagation Letters, 11, 1508-1511.

[9] Kiourti A., \& Nikita K. S. (2012). Miniature scalp-implantable antennas for telemetry in the MICS and ISM bands: Design, safety considerations and link budget analysis. IEEE Transactions on Antennas and Propagation, 60(8), 3568-3575.

[10] Karacolak T., Cooper R., \& Topsakal E. (2009).Electrical properties of rat skin and design of implantable antennas for medical wireless telemetry. IEEE Transactions on Antennas and Propagation, 57(9), 2806-2812.

[11] Mohamed A. E., \& Sharawi M. S. (2017). Miniaturized dualwideband circular patch antenna for biomedical telemetry. 2017 11th European Conference on Antennas and Propagation (EUCAP), 1027-1030.

[12] Ding S., Koulouridis S. and Pichon L., "A Dual-Band Miniaturized Circular Antenna for Deep in Body Biomedical Wireless Applications," 2019 13th European Conference on Antennas and Propagation (EuCAP), Krakow, Poland, 2019, pp. 1-4.

[13] Shubair R. M., Salah A., \& Abbas A. K. (2015). Novel implantable miniaturized circular microstrip antenna for biomedical telemetry. IEEE Antennas and Propagation Society, AP-S International Symposium (Digest), 2015-October(c), 947-948.

[14] Computer Simulation Technology (CST) STUDIO SUITE. Ver 2017, CST AG, Germany

[15] IEEE standard for safety levels with respect to human exposure to radiofrequency electromagnetic fields, $3 \mathrm{kHz}$ to $300 \mathrm{GHz}$, IEEE Standard C95.1, 1999.

[16] IEEE standard for safety levels with respect to human exposure to radiofrequency electromagnetic fields, $3 \mathrm{kHz}$ to $300 \mathrm{GHz}$, IEEE Standard C95.1, 2005

[17] International Telecommunications Union. (1998). Recommendation ITU-R RS.1346.

[18] FCC 15. 209, Standard Specification for Radiated emission limits, general requirements

[19] Bakogianni S., Koulouridis S. (2016). Design of a Novel Miniature Implantable Rectenna for In-Body Medical Devices Power Support. 2016 10Th European Conference on Antennas and Propagation (Eucap).

[20] Sauter M. (2010). From GSM to LTE. An Introduction to Mobile Networks and Mobile Broadband, Wiley, 2014, pp. 251.

[21] Ding S., Koulouridis S. and Pichon L., "Miniaturized implantable power transmission system for biomedical wireless applications" in Wireless Power Transfer, Cambridge University Press, to be published.

[22] Gabriel S., Lau R., and Gabriel C., "The dielectric properties of biological tissues: II. Measurements on the frequency range $10 \mathrm{~Hz}$ to 20 GHz,’Phys.Med. Biol., vol. 41, pp. 2251-2269, 1996.

[23] Vallejo M., Recas J., del Valle P.G., Ayala J.L. Accurate Human Tissue Characterization for Energy-Efficient Wireless On-Body Communications. Sensors. 2013;13:7546-7569

[24] Deneris Z. A., Pe'a D. E. and Furse C. M., "A Layered Pork Model for Subdermal Antenna Tests at $433 \mathrm{MHz}$," in IEEE Journal of
Electromagnetics, RF and Microwaves in Medicine and Biology, vol. 3, no. 3, pp. 171-176, Sept. 2019. 